\title{
Proposal for Streamlining the Railway Infrastructure Capacity on the Specific Track Section in the Context of Establishing an Integrated Transport System
}

\author{
Ondrej Stopka ${ }^{1, *}$, Mária Chovancová $^{1}$, and Rudolf Kampf ${ }^{1}$ \\ ${ }^{1}$ Institute of Technology and Business in České Budějovice, Faculty of Technology, Okružní 517/10, \\ 37001 České Budějovice, Czech Republic
}

\begin{abstract}
This paper is processed based on assessing the current capacity condition of the specific railway track section which connects two cities. Particularly, it proposes a set of possible measures in order to increase the permeable railway tracks performance (permeability) for the purpose of establishing an integrated transport system. In detail, it examines the capacity solutions by the construction of a double-track liner for smooth crossing and a second track on a single-track railway section.
\end{abstract}

\section{Introduction}

For a long time, individual regions of the Slovak Republic have been trying to find effective ways to harmonize, and especially, make public passenger transport more attractive, and thus attract new customers. Providing the railway infrastructure represents a prerequisite to achieve a high-quality public passenger transport which could be considered as the skeleton of the entire transport system, not only in the national, but also in the regional conception.

Thus, integrated transport system (ITS) becomes an alternative for individual car (car passenger) transport and passengers have more options to choose how to reach their journey destination more comfortably.

When considering the increase of the railway infrastructure capacity, the required range of railway transport plays a major role in the specific railway section. All the adjustments and upgrades affecting the railway track over decades must be reflected from the required range of railway transport. First of all, it is necessary to analyze the current state (condition) of infrastructure capacity to make it clear what changes can be expected in terms of number of trains.

The Košice - Prešov transport relation (railway track section) is included into the Košice and Prešov self-governing regions. Individual self-governing regions have some intentions that they would like to apply to this section in order to improve transport serviceability between these cities and adjacent cities and municipalities [1-3].

* Corresponding author: stopka@mail.vstecb.cz 


\section{Transport policy and the "Masterplan" for the development of railway infrastructure by 2020}

The Strategy for the Development of Transport Infrastructure of the Slovak Republic by 2020 and the Strategy for the Development of Public Passenger Transport of the Slovak Republic by 2020 identified especially the capacity and safety limitations of railway infrastructure and inappropriate equipment of carriers' fleet as the main constraints of this situation in the Slovak Republic. This results in limited speed of cargo and passengers' transportation and reduced reliability of this transport mode [4].

In 2013, the Ministry of Transport, Construction and Regional Development of the Slovak Republic drafted a transport plan aimed at improving the quality of transport infrastructure and the quality of provided transport services under the title "Masterplan" [4].

In regard to transport policy and the current state in the field of railway transport, the main issues and the resulting needs are defined as:

- balance between transport offer and transport demand,

- balance between infrastructure offer and transport demand,

- establishing the conditions for the proper railways operation.

The realization of these visions will be done through the implementation (fulfillment) of the partial strategic objectives including, as follows [4]:

- quality and competitive railway passenger transport,

- high-quality and competitive railway freight transport,

- modern and safe railway infrastructure,

- efficient organization and planning the railways development,

- economically sustainable railways.

\section{Traffic flows of the Košice integrated transport system}

In the Kysak - Prešov railway track section, the early-morning heavy traffic flow is divided into two sections, one part directs into Prešov station and second part into Lipany. Transport demand in Lipany - Prešov section is spread almost evenly throughout the day. The backflow is spread over two time periods in the afternoon and evening, and the traffic rush-hour is repeated in reverse direction. Passengers' traffic flows per day are processed separately for each direction in Table 1. It contains a statistical overview of passengers' flows from Košice to Prešov and Table 2 summarizes flows from Prešov to Košice.

Table 1. Passengers' traffic flows - direction into Prešov (in 2015). Source: [5]

\begin{tabular}{|l|c|c|c|}
\hline Track number & $\begin{array}{c}\text { Track } \\
\text { direction }\end{array}$ & Railway track section & $\begin{array}{c}\text { Number of } \\
\text { passengers }\end{array}$ \\
\hline \multirow{4}{*}{188} & Košice - Ťahanovce & 2,945 \\
\cline { 3 - 4 } & \multirow{4}{*}{ Košice - Prešov } & 2,982 \\
\cline { 3 - 4 } & Ťahanovce - Kostol'any n. & 2,440 \\
\cline { 3 - 4 } & Kostol'any n. Hornádom & 2,372 \\
\cline { 3 - 4 } & Trebejov - Kysak & 1,519 \\
\cline { 3 - 4 } & & Kysak - Ličartovce & 1,562 \\
\cline { 3 - 4 } & & Ličartovce - Drienovská n. Ves & 1,596 \\
\cline { 3 - 4 } & Drienovské n. Ves - Kendice & 1,602 \\
\cline { 3 - 4 } & Kendice - Haniská pri Prešove & 1,751 \\
\cline { 3 - 4 } & & Haniská pri Prešove - Prešov & \\
\hline
\end{tabular}


Table 2. Passengers' traffic flows - direction into Košice (in 2015). Source: [5]

\begin{tabular}{|c|c|c|c|}
\hline Track number & $\begin{array}{c}\text { Track } \\
\text { direction }\end{array}$ & Railway track section & $\begin{array}{l}\text { Number of } \\
\text { passengers }\end{array}$ \\
\hline \multirow{9}{*}{188} & \multirow{9}{*}{ Prešov - Košice } & Prešov - Haniská pri Prešove & 1,590 \\
\hline & & Haniská pri Prešove - Kendice & 1,588 \\
\hline & & Kendice - Drienovská n. Ves & 1,498 \\
\hline & & Drienovská n. Ves - Ličartovce & 1,438 \\
\hline & & Ličartovce - Kysak & 1,446 \\
\hline & & Kysak - Trebejov & 1,872 \\
\hline & & Trebejov - Kostol'any n. Hornádom & 1,900 \\
\hline & & $\begin{array}{c}\text { Kostol'any n. Hornádom - } \\
\text { Ťahanovce }\end{array}$ & 2,227 \\
\hline & & Ťahanovce - Košice & 2,125 \\
\hline
\end{tabular}

\section{Railway infrastructure between the cities of Prešov and Košice}

The railway track section connecting the cities of Prešov and Košice is $33 \mathrm{~km}$ long, for which the streamlining is proposed, consists of two tracks on a network of the Železnice Slovenskej republiky (ŽSR; Railways of the Slovak Republic). These include the track designated by the number 188 (Košice - Prešov - Plaveč) and the track 180 (Košice Poprad - Tatry - Žilina), which has a common numbering with the track 188 in the Košice Kysak section; according to the numbering in the book timetable.

The traffic management is decentralized, which means that the management is provided by the transport staff directly in railways operating buildings. There is also a remote (dispatcher) controlled track between the cities of Kysak and Ličartovce on the assessed infrastructure section. All the operating buildings are constantly occupied without the transport service lockout [6-9].

In the Košice - Kysak section, the railway infrastructure connecting the cities of Prešov and Košice is built as a double-track, $16 \mathrm{~km}$ long, and in the Kysak - Prešov section, this infrastructure is built as a single-track and $17 \mathrm{~km}$ long. According to the ŽSR railway tracks categorization, the whole Košice - Prešov section is included among tracks of 1st category.

Fig. 1 depicts a track section scheme showing the stations and stops located on this section as well as the branch (turning) tracks from the railway stations Košice, Kysak and Prešov.

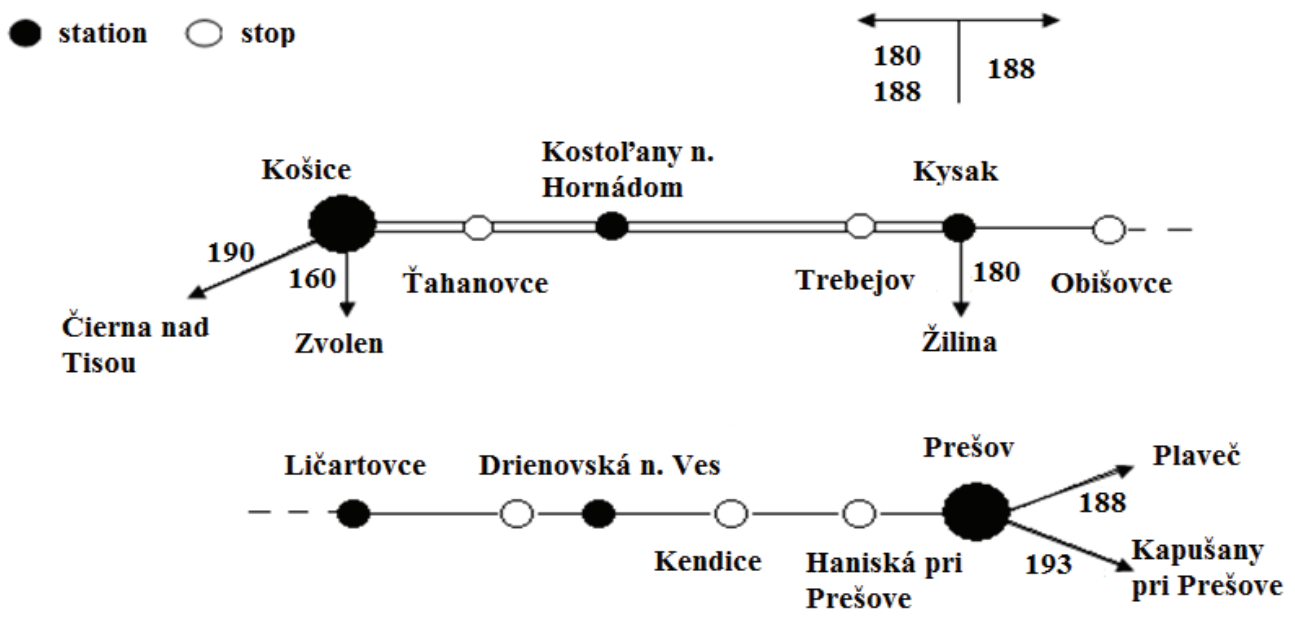

Fig. 1. Košice - Prešov track section scheme. Source: authors 


\section{Results}

Based on the analysis of passengers' flows and identification of a possible maximum range of transport performance offer within regional passenger transport, the railway infrastructure capacity options between the cities of Košice and Prešov, in the context of implementation of interval transport within the planned ITS, are assessed.

On the basis of the knowledge of a set of possible measures for increasing the permeable performance of railway tracks and the knowledge of the railway infrastructure condition in the assessed track section, further, the following alternative measures will be developed:

- construction of a double-track liner for smooth crossing,

- construction of a second track on a single-track railway section.

\subsection{Railway tracks permeability indicators in the current state}

For the purpose of the permeability calculation, identified facts by analyzing the elements of the train graph schedule diagram (TGS) in 2015, such as interstation section occupation times, station and track intervals, and so on. Table 3summarizes the numbers of operated connections and the capacity for the Prešov - Košice section.

Table 3. Numbers of operated connections within the TGS (in 2015). Source: [10]

\begin{tabular}{|c|c|c|c|c|c|c|c|c|c|c|}
\hline \multirow{3}{*}{$\begin{array}{c}\text { Track } \\
\text { number }\end{array}$} & \multirow{3}{*}{$\begin{array}{c}\text { Track } \\
\text { section }\end{array}$} & \multirow{3}{*}{ Train type } & \multicolumn{8}{|c|}{ Number of connections } \\
\hline & & & \multicolumn{2}{|c|}{$\begin{array}{c}\text { Regular - in } \\
\text { TGS }\end{array}$} & \multicolumn{2}{|c|}{$\begin{array}{l}\text { As needed - } \\
\text { in TGS }\end{array}$} & \multicolumn{2}{|c|}{ Free capacity } & \multicolumn{2}{|c|}{ Capacity } \\
\hline & & & $\mathrm{E}$ & $\mathrm{O}$ & $\mathrm{E}$ & $\mathrm{O}$ & E & $\mathrm{O}$ & $\mathrm{E}$ & $\mathrm{O}$ \\
\hline \multirow{2}{*}{$105 \mathrm{~A}$} & \multirow{2}{*}{$\begin{array}{c}\text { Košice - } \\
\text { Kysak }\end{array}$} & Passenger & 47 & 48 & 2 & 1 & \multirow{2}{*}{79} & \multirow{2}{*}{74} & \multirow{2}{*}{173} & \multirow{2}{*}{171} \\
\hline & & Freight & 24 & 25 & 21 & 23 & & & & \\
\hline \multirow{2}{*}{$107 \mathrm{~A}$} & \multirow{2}{*}{$\begin{array}{l}\text { Prešov - } \\
\text { Kysak }\end{array}$} & Passenger & 21 & 20 & 0 & 0 & \multirow{2}{*}{\multicolumn{2}{|c|}{35}} & \multirow{2}{*}{\multicolumn{2}{|c|}{96}} \\
\hline & & Freight & 5 & 5 & 5 & 5 & & & & \\
\hline
\end{tabular}

Explanations: E - even train direction; O - odd train direction; TGS - train graph schedule diagram

Table 4 contains calculated parameters characterizing the current state of the Prešov Košice track section permeability.

Table 4.Prešov - Košice track section permeability (in 2015). Source: authors

\begin{tabular}{|c|c|c|c|c|c|c|c|c|c|}
\hline \multirow{2}{*}{ Track section } & \multirow{2}{*}{ Direction } & \multirow{2}{*}{ Total number of trains } & $\mathrm{T}_{\text {occ }}$ & $\mathrm{T}_{\text {gap }}$ & $\mathrm{N}_{\text {add }}$ & $\mathrm{N}_{\mathrm{ar}}$ & $\mathrm{D}_{\mathrm{o}}$ & \multirow{2}{*}{$\mathrm{C}_{\mathrm{p}}$} & $t_{1}$ \\
\hline & & & $t_{o c c}$ & $t_{\text {gap }}$ & $\mathrm{p}$ & $t_{\text {fix }}$ & $\mathrm{b}$ & & \\
\hline \multirow{4}{*}{ Prešov - Kysak } & $\mathrm{E}$ & 26 & 1,165 & 275 & 39 & 35 & 0.43 & \multirow{2}{*}{52.9} & 52 \\
\hline & AN & 5 & 11.65 & 2.75 & 96 & 0 & 15.6 & & $\mathrm{x}$ \\
\hline & $\mathrm{O}$ & 25 & $\mathrm{x}$ & $\mathrm{x}$ & $\mathrm{x}$ & $\mathrm{x}$ & $\mathrm{x}$ & \multirow{2}{*}{$\mathrm{x}$} & $x$ \\
\hline & AN & 5 & $\mathrm{x}$ & $\mathrm{x}$ & $\mathrm{x}$ & $\mathrm{x}$ & $x$ & & $\mathrm{x}$ \\
\hline
\end{tabular}

Explanations: $E$ - even train direction; $O$ - odd train direction; $T_{\text {occ }}$ - total occupation time of the interstation section by all trains $[d] ; t_{\text {occ }}-$ occupation time per one train $[d] ; T_{\text {gap }}$ - total gaps time [d]; $t_{\text {gap }}-$ gaps time per one train [d]; $N_{\text {add }}$ - number of additional routes; $p$ - practical permeability $[t / d] ; N_{a r}-$ number of added routes; $t_{f i x}-$ time of fixed operations per one train [d]; $D_{o}$ - occupation degree; $b$-backups time [d]; $C_{p}$-coefficient of the permeability utilization; $t_{l}-$ lockouts time [d] 
Table 5 contains calculated parameters characterizing the current state of the Košice Kysak track section permeability.

Table 5.Košice-Kysaktrack section permeability (in 2015). Source: authors

\begin{tabular}{|c|c|c|c|c|c|c|c|c|c|}
\hline \multirow{2}{*}{ Track section } & \multirow{2}{*}{ Direction } & \multirow{2}{*}{ Total number of trains } & $\mathrm{T}_{\mathrm{occ}}$ & $\mathrm{T}_{\text {gap }}$ & $\mathrm{N}_{\mathrm{add}}$ & $\mathrm{N}_{\mathrm{ar}}$ & $\mathrm{D}_{\mathrm{o}}$ & \multirow{2}{*}{$\mathrm{C}_{\mathrm{p}}$} & $t_{1}$ \\
\hline & & & $t_{\text {occ }}$ & $t_{\text {gap }}$ & $\mathrm{p}$ & $t_{\text {fix }}$ & $\mathrm{b}$ & & \\
\hline \multirow{4}{*}{ Košice - Kysak } & $\mathrm{E}$ & 71 & 1,269 & 171 & 87 & 79 & 0.36 & \multirow{2}{*}{40.9} & 60 \\
\hline & AN & 23 & 7.01 & 0.94 & 173 & 0 & 12.4 & & $\mathrm{x}$ \\
\hline & $\mathrm{O}$ & 73 & 1,262 & 178 & 83 & 74 & 0.38 & \multirow{2}{*}{42.8} & 60 \\
\hline & AN & 24 & 7.09 & 1 & 171 & 0 & 11.8 & & $\mathrm{x}$ \\
\hline
\end{tabular}

\subsection{Calculation of the Kysak - Prešov track section permeability after the construction of a double-track liner for smooth crossing}

In the case of insertion of a double-track section into a single-track line on the Kysak Prešov section, the permeability will be favorably influenced by the fact that trains in the double-track section will be able to cross during the movement (smooth crossing).

In order to meet this goal, it is necessary to determine the optimum length of a doubletrack liner (section) with the corresponding safety device (see equation 1) [11-14]:

$$
L_{k}=\frac{\left(\tau_{p v}^{A}+\tau_{p v}^{B}\right) *\left(v_{1} * v_{2}\right)}{\left(v_{1}+v_{2}\right) * 0.06}=\frac{(2+2) *(40 * 44)}{(40+44) * 0.06}=1,396.83 \mathrm{~m}
$$

where: $L_{k}$ - the minimum distance of the double-track liner for smooth crossing $[\mathrm{m}] ; v_{1}-$ speed of the first train $[\mathrm{km} / \mathrm{h}] ; v_{2}-$ speed of the second train $[\mathrm{km} / \mathrm{h}] ; \tau_{p v}{ }^{A}$ - interval of successive entrances in the railway operating building $\mathrm{A} ; \tau_{p v}{ }^{B}-$ interval of successive entrances in the railway operating building B.

From the above calculation, it is clear that the length of a double-track liner for smooth crossing must be at least $1397 \mathrm{~m}$. After the performed analysis of the track section, it would be most efficient to build a double-track liner in a constraining section of the single-track line between Drienovská nová Ves station and Haniská pri Prešove station. The distance between these two points is $5,100 \mathrm{~m}$, which meets the condition of the minimum distance of a double-track liner for smooth crossing.

Table 6summarizes calculated parameters characterizing the Košice - Kysak track section permeability after the construction of a double-track liner.

Table 6.Košice-Kysaktrack section permeability after the construction of a double-track liner (in 2015). Source: authors

\begin{tabular}{|c|c|c|c|c|c|c|c|c|}
\hline \multirow{2}{*}{ Track section } & \multirow{2}{*}{ Direction } & \multirow{2}{*}{ Total number of trains } & $\mathrm{T}_{\text {occ }}$ & $\mathrm{T}_{\text {gap }}$ & $\mathrm{N}_{\text {add }}$ & $\mathrm{N}_{\mathrm{ar}}$ & \multirow{2}{*}{$\mathrm{Cp}$} & $t_{1}$ \\
\hline & & & $\mathrm{t}_{\mathrm{occ}}$ & $t_{\text {gap }}$ & $\mathrm{p}$ & $t_{\text {fix }}$ & & \\
\hline \multirow{4}{*}{ Košice - Kysak } & E & 71 & 379 & 1,000 & $\mathrm{x}$ & 0.27 & \multirow{2}{*}{44.85} & 60 \\
\hline & AN & 23 & 6.22 & 16.4 & 136 & 12.4 & & $\mathrm{x}$ \\
\hline & $\mathrm{O}$ & 73 & $\mathrm{x}$ & $\mathrm{x}$ & $\mathrm{x}$ & $\mathrm{x}$ & \multirow{2}{*}{$\mathrm{x}$} & $\mathrm{x}$ \\
\hline & AN & 24 & $\mathrm{x}$ & $\mathrm{x}$ & $\mathrm{x}$ & $\mathrm{x}$ & & $\mathrm{x}$ \\
\hline
\end{tabular}

From above calculations, it is obvious that, after the construction of a double-track liner for smooth crossing in the given track section, its capacity has a potential to significantly increase from the original 96 trains per day to 136 trains per day. At present, 61 train 
connections are operated on this track section, which means that other 75 train connections can be deployed after implementing this measure $[11,12]$.

\subsection{Calculation of the Košice - Prešov track section permeability after the construction of a second railway track}

Construction of new railway tracks, or double-tracking railway sections, has a high positive effect in terms of increasing the capacity of the assessed section. For such construction measures, the permeability is increased by more than $100 \%$. When decision-making such as double-tracking a railway section, it is necessary to equip the entire section not only with a new railway track but also a new railway safety device, which has a positive effect on the permeability of the track section as well [14-17].

Similarly to all operating devices, it is necessary to determine the practical permeability of the railway tracks separately (see equation 2 for even direction and equation 3 for odd direction) [18-20]:

$$
\begin{aligned}
& n_{E}=\frac{T_{o c c}-\left(T_{E}+T_{o i s}\right)}{t_{o c c}+t_{\text {gapp }}}=\frac{1,440-(0+0)}{(4+4)}=180 \mathrm{t} / \mathrm{d} \\
& n_{O}=\frac{T_{o c c}-\left(T_{E}+T_{o i s}\right)}{t_{o c c}+t_{\text {gapp }}}=\frac{1,440-(0+0)}{(4+4)}=180 \mathrm{t} / \mathrm{d}
\end{aligned}
$$

where: $n_{E}$ - practical permeability for even direction [trains per day $=\mathrm{t} / \mathrm{d}$ ]; $n_{O}-$ practical permeability for odd direction [t/d]; $T_{E}$ - total time needed for regular scheduled examinations [d]; $T_{\text {ois }}$ - occupation time of an inter-station section by regular siding, operating and service trains which are not included in the number of trains $[\mathrm{d}] ; t_{\text {occ }}-$ average occupation time per one train [d]; $t_{\text {gap }}$ - required gaps time per one train [d].

After calculations, it is clear that the practical permeability is for even and odd directions of 180 trains per day [21].

\section{Discussion}

After the made calculations, it is necessary to evaluate the individual design measures. Fig. 2 shows comparison of the practical permeability of the examined railway track section for the current state (without applied measures) and the proposed measures variants; a doubletrack liner and a complete double-tracking [22-24].

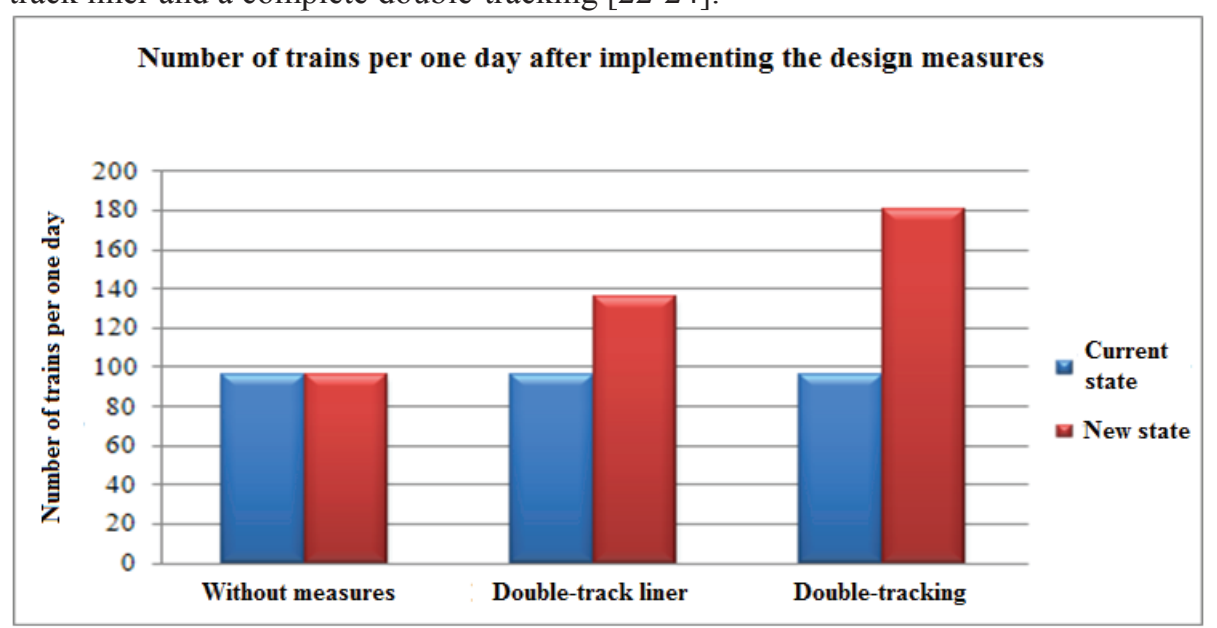

Fig. 2. Comparison of the original permeability and permeability after modernization. Source: authors 
Following the section upgrade, i.e. the construction of a double-track liner for smooth crossing, the section capacity would increase from the original 96 trains per day to 136 trains per day.

Double-tracking the whole section from the Prešov station to Kysak station represents next design measure. This most demanding measure in terms of investments also has the most favorable impact on the whole section capacity, while the permeability would increase from the original 96 trains per day in both directions to 180 trains per day in both the even and the odd direction [25-27].

\section{Conclusion}

As mentioned above, when considering the increase of the railway infrastructure permeable performance from an integrated transport system establishment point of view, the required range of connections within railway transport plays a major role in particular railway section. All the changes affecting the railway track must be based on this railway transport range.

Košice - Kysak - Prešov railway connection represents a link of two important settlements, the centers of regional departments and creates significant interconnection within the functional unit. On this interconnection, considerable demands on the quality and capacity of the railway infrastructure, especially in terms of its utilization for the creation of a primary system within an integrated transport system.

Among the potential regional railway tracks, where significant investments could be made available, the track between the cities of Prešov and Košice can be included. It has a high passengers transportation potential between cities and a strong current traffic flow.

This paper is supported by the research project "From horse-drawn railway to intermodal transport" within Visegrad Fund.

\section{References}

1. G.C. Li, B.R. Li, M.Y. Ju, Z.J. Zhang, WCTR - 14th World Conference on Transport Research, 3402-3415 (Transportation Research Procedia 25, Shanghai, China, 2017), DOI: $10.1016 /$ j.trpro.2017.05.231

2. V. Molnar, CLC 2013 - Carpathian Logistics Congress, 561-566 (Krakow, Poland, 2014)

3. J. Ližbetin, L. Černá, M. Loch, Nase More 62, 3, 147-152 (2015), DOI: $10.17818 / \mathrm{NM} / 2015 / \mathrm{SI} 11$

4. Ministry of Transport, Construction and Regional Development of the Slovak Republic, Operačný program Integrovaná infraštruktúra 2014 - 2020, 5th revised draft (Bratislava, Slovak Republic, 2013)

5. Ministry of Transport, Construction and Regional Development of the Slovak Republic, Strategický plán rozvoja dopravnej infraštruktúry SR do roku 2020, $1^{\text {st }}$ phase (Bratislava, Slovak Republic, 2013)

6. D. Michniak, Quaestiones Geographicae 35, 4, 107-120 (2016), DOI: 10.1515/quageo-2016-0039

7. B. Abramovic, V. Zitricky, V. Biskup, European Transport Research Review 8, 4 (2016), DOI: 10.1007/s12544-016-0215-7 
8. K. Borsekova, M. Sokolowicz, 21st IntSciConf of PGV Network - For Stronger Europe Renovation of the Economic, Entrepreneural, Political, Territorial and Educational Structures, 179-194 (Banská Bystrica, Slovak Republic, 2016)

9. M. Nadanyiova, Transport Means - 18th International Scientific Conference on Transport Means, 120-124 (Kaunas, Lithuania, 2014)

10. ŽSR - Railways of the Slovak Republic, Book of the railway tracks permeability of the ŽSR for the TGS 2015/2016 (Bratislava, Slovak Republic, 2016)

11. R.L. Parsons, A.J. Rahman, J. Han, T.E. Glavinich, Transportation research Record 2448, 133-141 (2014), DOI: 10.3141/2448-16

12. Y.G. Zhang, Q.F. Zeng, D.Y. Lei, X.Y. Wang, Discrete Dynamics in Nature and Society, Article Number: 2319437 (2016), DOI: 10.1155/2016/2319437

13. B. Abramovic, V. Zitricky, P. Mesko, LOGI - Scientific Journal on Transport and Logistics 8, 1, 1-10 (2017), DOI:10.1515/logi-2017-0001

14. R.W.B. Stell, IEEE Vehicular Technology Magazine 6, 3, 99-105 (2011), DOI: 10.1109/MVT.2011.942537

15. J. Gasparik, V. Gaborova, V. Luptak, Transport Means - 20th International Scientific Conference on Transport Means, 245-249 (Juodkrante, Lithuania, 2016)

16. M. Sol-Sanchez, F. Moreno-Navarro, M.C. Rubio-Gamez, Materials 7, 8, 5903-5919 (2014), DOI: 10.3390/ma7085903

17. S.Y. Feng, L.M. Wei, C.Y. He, Q. He, Journal of Central South University 21, 7, 29212927 (2014), DOI: 10.1007/s11771-014-2258-Z

18. B. Poliaková, I. Kubasáková, Autobusy: technika, eksploatacja, systemy transportowe 5, 104-110 (2014)

19. G. Fedorko, H. Neradilova, M. Sutak, V. Molnar, Transport Means -20th International Scientific Conference on Transport Means, 169-174 (Juodkrante, Lithuania, 2016)

20. R. Francesco, M. Gabriele, R. Stefano, European Transport Research Review 8, 4 (2016), DOI: 10.1007/s12544-016-0216-6

21. J. Gasparik, V. Luptak, P. Mesko, ICTTE - 3rd International Conference on Traffic and Transport Engineering, 388-392 (Belgrade, Serbia, 2016)

22. J. Jagelčák, I. Kubasáková, NaseMore 61, 5-6, 106-116 (2014)

23. J. Gašparík, L. Pečený, P. Blaho, Regulovaná a neregulovaná konkurence na kolejích (Regulated and unregulated competition on rails), 40-48 (Telč, Brno: Masaryk University, Czech Republic, 2013)

24. V. Lendel, M. Varmus, Logi - Scientific Journal on Transport and Logistics 3, 2, 21-34 (2012)

25. J. Zamecnik, J. Jagelcak Communications: scientific letters of the University of Žilina 17, 4, 21-27 (2015)

26. L.X. Yang, X.S. Zhou, Z.Y. Gao, Omega-International Journal of Management Science 48, 75-93 (2014), DOI: 10.1016/j.omega.2013.11.004

27. Z. Cujan, G. Fedorko, Open Engineering 6, 426-431 (2016), DOI: 10.1515/eng-20160057 